
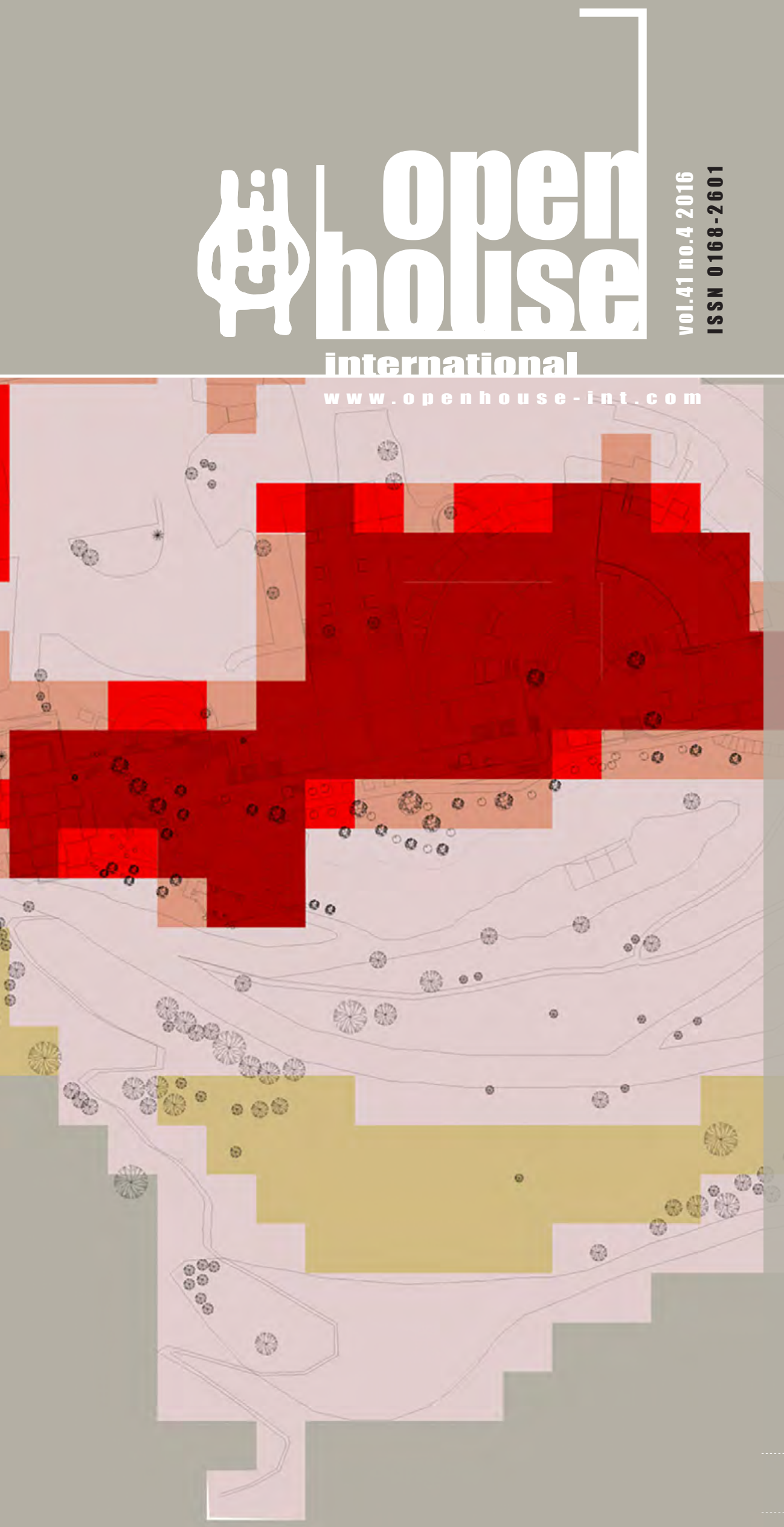

ThPMPRESTR:

FORGING ADUANGES IN SUSTAINABLE ARGHTEQTURE AND URBANISW

D Bsign for Bhang

Greg I U ba I is m

BuIf Bitios

Space / Nature Syntax

The Urban Laboratory

Traditional hasterplanning

Susta inable Urban Dovelopme in t

Urban Texture

Authors In this issue:

Aydın, Bagaeen, Barbour, Feliciotti, Grierson,

Ibrahim, Munro, Porta, Rae, Romice, Salama,

Wiedmann.

6

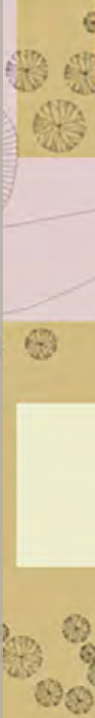

Elsevier Scopus

Thomson ISI Arts \& Humanities

EBSEO publishing

a HIB eneouraged journal 


\title{
UNFINISHED BUSINESS AT THE URBAN LABORATORY - PAOLO SOLERI, ARCOLOGY, AND ARCOSANTI.
}

\section{David Grierson}

\begin{abstract}
This paper reviews the prospect of a radical redefinition of the relationship between society, technology, and Nature as posited within Paolo Soleri's Arcology theory, and anticipates a transformative social order and environmental setting in support of sustainability as demonstrated within the urban laboratory Arcosanti. It locates the roots of Soleri's ecological architecture within a rejection of urban sprawl emerging from his early apprenticship with Frank Lloyd Wright at Taliesin West in Arizona, and argues that his own theoretical model, in presenting a fusion of architecture and ecology, prefigures a utopia of transcendence and offers a more rational planned response to the challenges of our age, while offering environmental movements a vision of what a sustainable urban future might look like. The paper argues that the positive utopian tendencies in Soleri's work should be reaffirmed and, at the same time, it underlines an urgent need for multi-aspect and multi-disciplinary research, and postgraduate education, to be undertaken at Arcosanti, to test the parameters of micro- and macro-structures within alternative models of ecological design. In concluding the paper gives acknowledgement to the ongoing work of the Cosanti Foundation's Board of Directors and its new Strategic Plan Steering Committee, and their commitment to attract renewed levels of financial and human resource in support of the urban laboratory's unfinished business.
\end{abstract}

Keywords: Arcology, Arcosanti, Ecological Design, Urban Sustainability, Utopia.

\section{INTRODUCTION}

This paper has been prepared since March of this year while I was working in the cities of Glasgow, Dubai, Doha Delft, Rotterdam, Xia'an, Hohhot, and Belfast. I 've taken this opportunity, since things have changed, to reflect on themes that I first presented at a conference in Manchester almost twenty years ago (Grierson, 1997), and to support a recent renewed engagement with Arcosanti, the unique laboratory located in the Arizona desert, where I lived and worked some years before that. The paper is about architecture, ecology, sustainability, and utopia.

Across the planet, in our 'traditional' cities, and more recently in the emerging 'global' cities of a new knowledge economy, an enlightened culture has gradually polished the essential achievements of our modern civilisation such that today our urban centres converge on the demands and preoccupations of a mobile, connected, largely consumer society, and in so doing seem to struggle (some more than others) to retain within their blurred boundries a sense of cultural identity. Each in their own way contain distinctly beautiful and vibrant places, but they each also have a darker side, one that fills the long shadows that extend ever outwards from the metropolis with anonimity. And it's here, not in the bustling street cafes and old market squares, nor in the regenerated docklands and artistic quarters, or even in the energy sapping shopping malls and office complexes, but in the designed sprawl of the endless suburbs of Europe, the Middle East, and China, and right across the developed world, that these cities collectively contribute to a built environment that, by distancing itself from Nature, has become insensitive to environmental and ecological limits. Limits that we now understand have been surpassed.

During the last century, as the global population has effectively exploded around the world, incremental progress has been achieved by extracting more and more non-renewable resource from the natural environment. The continuation of these levels of extraction is unsustainable. We have taken more than the planet can afford and have reached a crossroads. Which path we choose will depend upon what value we are willing to place on future generations and, almost of equal importance, on the kind of living environment we are bold enough to imagine. If we are to confront the most pressing social, environmental, and economic challenges of our age, architecture, ecology, and urban design must be directed, in the utopian tradition, towards the forging of radical new cities that can, not only house our aspirations for an enhanced human culture, but offer opportunities for a new social contract in equilibrium with Nature. Time is precious. The watchman on the hill is calling just beyond where the majority of us now live. His is a shrill cry, echoing across the hinterlands of a seemingly unstoppable" process of urbanisation' that speaks, not so much 


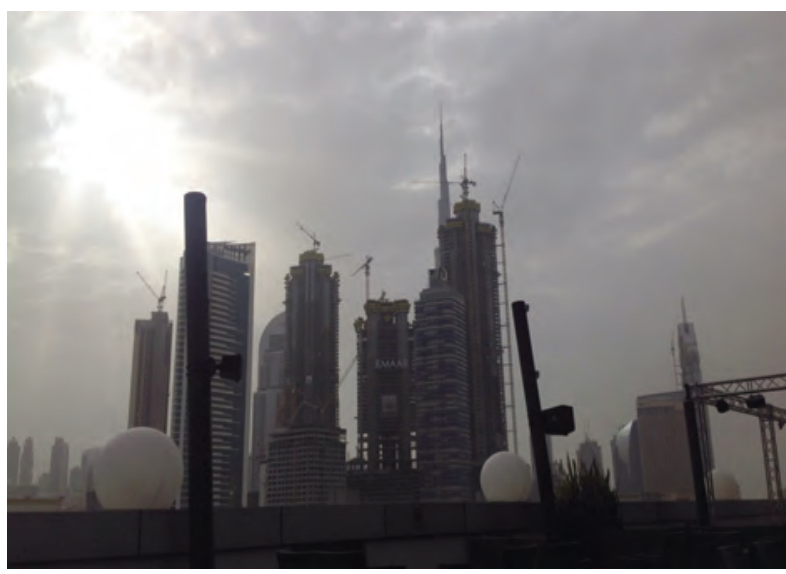

Figure 7. Business Bay, Dubai, UAE (Source: Author, Thursday 17 March, 2016).

about a city's evolutionary potential and predominance (its transformative capacity), but its increasing lack of identity. When a formless urbanity sprawls out across endless landscapes of development, devouring energy and resources and destroying people and land in its wake, we might be forgiven for feeling that today we actually live nowhere.

Since the 1950s a new form of semiurbanised space, forged by the mass mobilisation of the human population across Europe and the United States, has eroded our sense of organic community and of place. 'Urban sprawl' has become the transitory habitat for a new global nomadic society shifted from place to place, sometimes in flight from conflict, but more often under the directive of transnational corporations (or governments) who seek to sustain the growth machines of a slick economy that determines the new spatial order. But as the tax base has increasingly relocated to the suburbs, across the world our gigantic 'two-dimensional' cities are struggling simply to survive. As the urban core becomes starved of the financial and human capital that has helped sustain their industrial base many cities are now in danger of becoming extinct, while others compete for a niche in the global market. Alongside an accelerated process of urbanisation, the last fifty years has been marked by an intensification in our awareness that environmental problems arise within the context of a complex interrelationship between ourselves, our resource base, and the social and physical environments that we occupy. Consequentially questions about the objectives and strategies of conventional growth policies have been brought to the forefront of our public debates, and into the research agendas of our academies.

Lewis Mumford, in Technics and Civilization, advocated a new culture in which, rather than simply shaping our lives, a new form of humanistic technology, immersed in the social milieu, would become an evolutionary instrument enabling a better quality of life by actively enhancing our environmental setting. Mumford believed that mass communication, in better connecting us, would allow us to share our, " wishes, habits, ideas, and goals", and so build "a

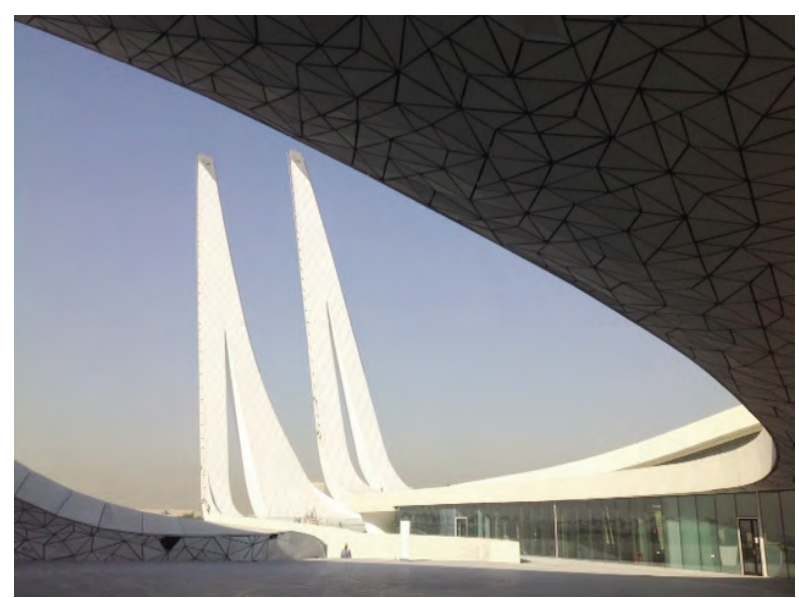

Figure 2. Faculty of Islamic Studies, Education City, Al

Rayyan, Doha, Qatar (Source: Author, Thursday 24 March, 2016).

better world for all" (Mumford, 1934). For our technology to be durable, effective, and efficient, he argued, it has to be fused with the kind of human spirit and creativity that will ensure that the message is more than just the media. Mumford's concept sanctions a transition towards an ecological view of the world that today's advances in communication technology have tantalisingly placed within our grasp (Grierson, 2014). A new knowledge-based economy and information order is emerging and is changing, not only the way many people work and how they spend their time, but transforming our collect consciousness. Simultaneoulsy, in opposition to a mechanistic paradigm that has, until now, infused all aspects of our modern lives with a predominantly instrumental view of Nature, we are witnessing a fundamental shift in our shared thinking towards a more ecological, holistic, organic, or systemic view of the world (Capra, 1982).

Lovelock's Gaia hypothesis sees the Earth as a self-regulating system which is impacted upon by humans but cannot be controlled by them. Conditions suitable for life are maintained by feedback processes involving both living things and the non-living part of the planet (Lovelock, 2009). In seeking homeostasis this complex system can adjust, within certain limits, to large-scale human technological interventions. But the current pattern of urbanisation, resulting as it does in energy-intensive, highly-pollutant, forms of human settlement represent interventions spiralling out of control, causing levels of environmental degradation and social disruptions that threaten the planet's equilibrium. As the mechanical paradigm recedes, and future technological developments become aligned with ecological values and the practice of sustainability, the search is on for a new form of settlement appropriate to the needs of a post-Fordist political economy, one that can respond to the demands of global, rather than national, modes of high-tech production, and simultaneously to a contemporary discourse upholding the belief that social and environmental problems arise largely from seeing ourselves as separate from Nature. Theories, ethics, and practice concerning sustainability indicate 


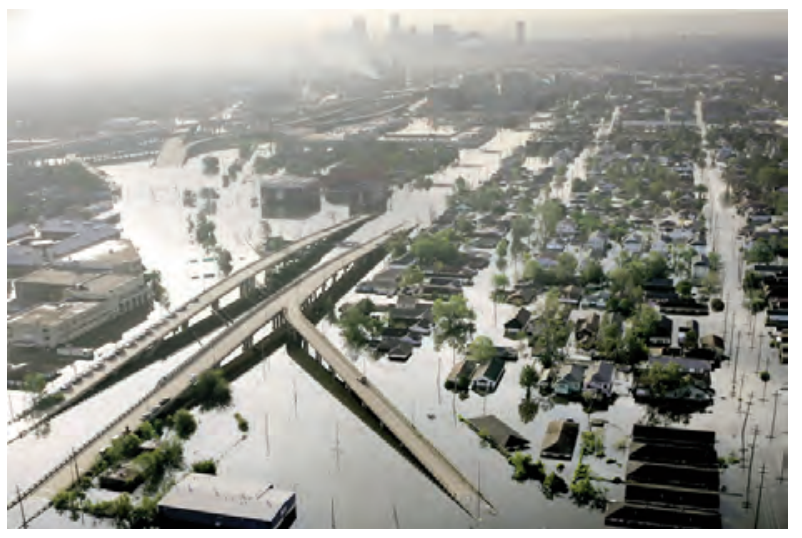

Figure 3. Floodwaters from Hurricane Katrina fill the streets near downtown New Orleans. (Source: AP/David J. Philip, 30 August, 2005.

an increasing concern that our conventional models of urban development are insufficient to respond to this new ecological world view (Grierson, 2003).

In provoking the prospect of a radical redefinition of the faltering relationship between society, technology, and Nature, we now anticipate a transformative economy, social order, and environmental setting in support of a new form of equilibrium, what we now commonly refer to as " sustainability'. Sustainability, in its widest sense, involves a move from a current condition of unsustainable activity towards a process of improvement and increased quality. Essentially the term is used to indicate a change of attitude prioritising ways of life that are in balance with the current renewable resources of the ecosystem and the biosphere. Although we are unclear about how much damage has already been inflicted on the biosphere the thesis proposes a precautionary approach as a practical way forward. The view is that, in the face of inherent uncertainty, risk is deemed inappropriate, since failure to maintain a viable biosphere will be catastrophic and irreversible (Grierson, 2003).

\section{THE ARCOLOGY THEORY}

In his Arcology theory Paolo Soleri has proposed a different way of life within a new kind of city ("arcology " - an urban structure planned to exhibit the fusion of 'architecture' with 'ecology'). Rather than accept the inevitability of decentralisation and sprawl, Paolo envisaged a re-orientation of life through a process of urban implosion, wherein the city is planned in such a way as to conserve the Earth's energy and resources, designed to be compact and three-dimensional. His version of the city imitates evolution via an intense miniaturisation process by becoming a single recycling organic structure. Citizens would occupy the outer skin of a complex structure that faces toward a Nature which is 'allowed', once again, to be natural. The surface is a membrane and not a wall, the interior contains the truly civic space, surrounded by real wilderness. The city turns inward for the concerns of people, society, and culture (Thompson, 1973). The theory refutes the Arcadian view that by moving to the wilderness we can escape the 'degradation of the city '. Rather Paolo foresaw that a truly urban response to providing shelter lies in recasting the relationship between architecture and ecology so that the integrity of the environment is preserved because quality of life is kept intact (Skolimowski, 1971). While Arcology offers a methodology for the reorganisation of urban sprawl into dense, integrated, compact city structures that contain the promise a renewed social and cultural intensity, two aspects fundamental to Paolo Soleri's work; the idea of planning and the notion of structuralism were rejected during the 1970's and 80 's in favour of the Postmodern notion that we might choose to live our lives wherever, and however, we pleased. Today we understand that ecological limits are predicated on technological and social problems manifest in the built environment, and that defining a more sustainable society will require that we address these through designed alternatives. The critical voices from the past that denied the certitudes that Soleri based his ideas upon, and decried his utopian tendency, are today giving way to a new generation of architects who are embracing the need to deploy integrated renewable energy systems within largescale, high density, urban agglomerations designed to respond to the need for sustainability in the built environment. Some, like Kevin Schopfer, describe their proposals as "arcologies". For them, Soleri's fusion of architectural technology with ecological conviction, offers a more rational planned response to the challenges of our age [note 1].

\section{PAOLO SOLERI (1919 - 2013) The Apprentice}

Paolo Soleri was born was born in the industrial part of Turin, Italy, on June 21 1919. Between 1941 and 1946 Paolo studied at the Turin Polytechnical Institute, where he graduated with highest honours taking a doctorate in architecture focused on 'human ecology'

Soleri's early architectural studies in Italy were influenced, like many of his contemporaries in Europe, by the work of Le Corbusier, Mendelsohn, Gropius and Aalto (Stanishev, 1993) but "suddenly this little booklet comes out in Italian on Frank Lloyd Wright with a photo of the desert thing. And it threw me" (Ostler, 1994). After a brief exchange of letters with Wright, Soleri joined an expanding group of post-war foreign apprentices who were then converging on Taliesin to hear at first hand Wright's radical views on the new architecture of American democracy.

It was traditional for apprentices around this time to give Wright a gift at Christmas and on his birthday. The 'Box' contained the students own architectural projects and offered an otherwise rare opportunity to obtain direct feedback from the 'master architect' on their own imaginative terms. Wright put great emphasis on this event and his comments were seen as "the greatest architectural critiques any apprentice would ever receive" (Pfeiffer, 1982). Paolo, one of Wright's 'most brilliant students' (Blake, 1969), presented his box in the summer of 1948. In his letter of response Wright wrote that: 


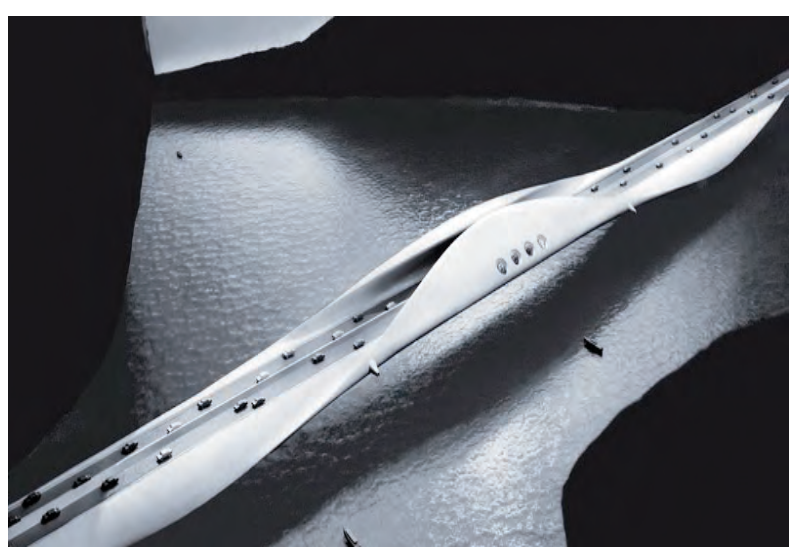

Figure 4. The Beast Bridge, Paolo Soleri, 1947-1948

(Source: Atlas Cement Corporation).

"Paolo really went to town on his. His passionate rendering had a painter's virtuosity and technique... The plateau he mounted his well conceived building scheme upon was richly decorated by his buildings. But again they seemed to me all on the plateau, not of it. And there again even in scheme Paolo seemed more the brilliant painter than the Architect. But there are many roads to Architecture and he may find one of them if he is patient enough (Pfeiffer, 1982)."

Less than a year later, the young Soleri's apprenticeship was abruptly terminated with a polite letter of dismissal from Wright. He had not, it seems, been patient enough. He had asked Wright's permission to establish another Taliesin in Italy and, although initially enthusiastic, Wright had become upset to discover that a group of Paolo's fellow apprentices were keen to join him in Europe, and when he discovered that Soleri's design for a bridge had been published in Mock's The Architecture of Bridges (1949) alongside his own, and had attracted better reviews, Paolo was on his way out of Taliesin.

Wright's decentralised view of American society, expressed through his life's work on Broadacre City was based on the general mobilisation of the individual through the widest possible use of the motor car. For Paolo the car came to represent, "...the

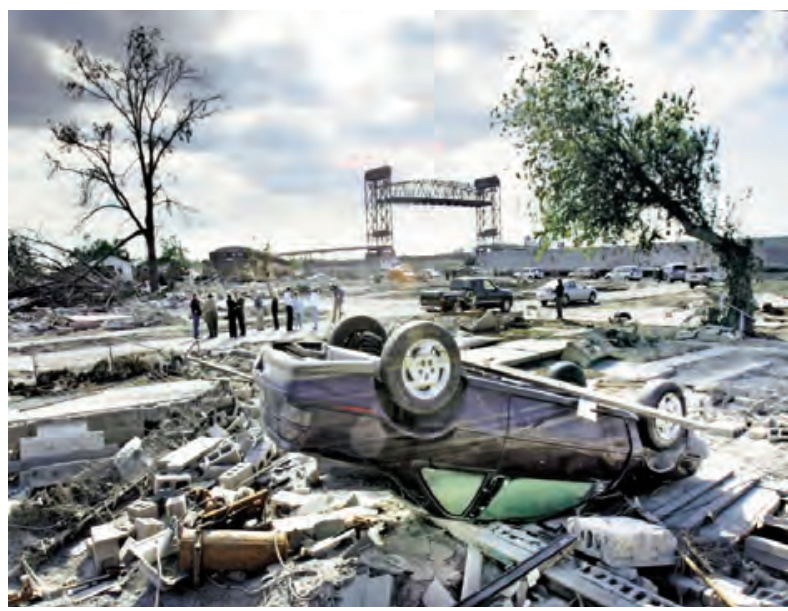

Figure 5. Damage caused by Hurricane near downtown New Orleans. (Source: Newsweek, 2005).

$-66$ great villain of the century, and quite possibly the great villain of all time... an apocalyptic example of mindless logistics and technological slavery" (Soleri, 1973).

The arcological alternative, in the centrist tradition of Sant'Elia (1914), Garnier (1917) and Le Corbusier (1922), brings people and their activities back together, and his approach was firmly rooted in a form of ecological design that would minimise environmentally destructive impacts by integrating itself with living processes (Van Der Ryn and Cowan, 1995). In promoting reductions in energy and material flows through the urban system, and allowing communities to be re-integrated within their surrounding ecosystems Soleri collocates architecture with ecology, and offers to the city an opportunity to be part of Nature, rather than be imposed upon it.

\section{UTOPIA \\ Change is 'on the way'}

The issue of Green social change is dogged by the necessity to distinguish between various manifestations and scales of the 'environmental crisis' (in reality a crisis of the spirit). Although we can, and should, 'act locally' there are clearly problems of a global nature that require a different response from those of a personal, immediate, and local nature.

The scale of our global (and necessarily urban) social and environmental problems is such that bringing about a sustainable society is an infinitely more complex and difficult task than simply placing environmentalism on the political agenda.

To build a better world for all we need visions of what a sustainable futures might look like, in effect to reclaim the utopian tradition.

"...the utopian vision provides the indispensable fundamentalist well of inspiration from which green activists, even the most reformist and

respectable, need continually to draw. Green reformers need a radical alternative picture of postindustrial society, they need deep ecological

visionaries, they need the phantom studies of the sustainable society, and they need, paradoxically, occasionally, to be brought down to earth and to be reminded about limits to growth" (Dobson, 2007).

Whereas much attention over the last 30 years (since the WCED in 1987) has focussed on the development of local environmental policies and in devising concrete solutions for highly specific problems, there is now a recognised need to find holistic visions, and evocative images of what a sustainable society might be like, particularly in an age when we appear to have lost faith in the future.

In an address to the Fifth Alvar Aalto Symposium in 1991, the architect, Juhani Pallasmaa contrasted the optimistic spirit in the artistic and cultural avant garde within La Belle Epoque, Art Nouveau, and De Stijl of a hundred years ago with our modern pre-occupation with 'endism' [note 2]. Now, he said, "...we simply do not know what to expect and what to hope. We have lost sight of our 


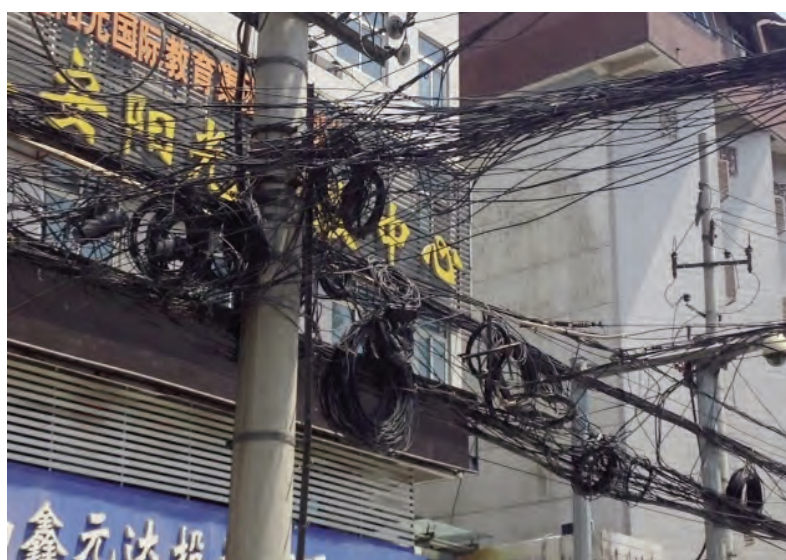

Figure 6. Steetscape, Xi'an, Shaanxi, China. (Source: Author, Sunday 29 May, 2016).

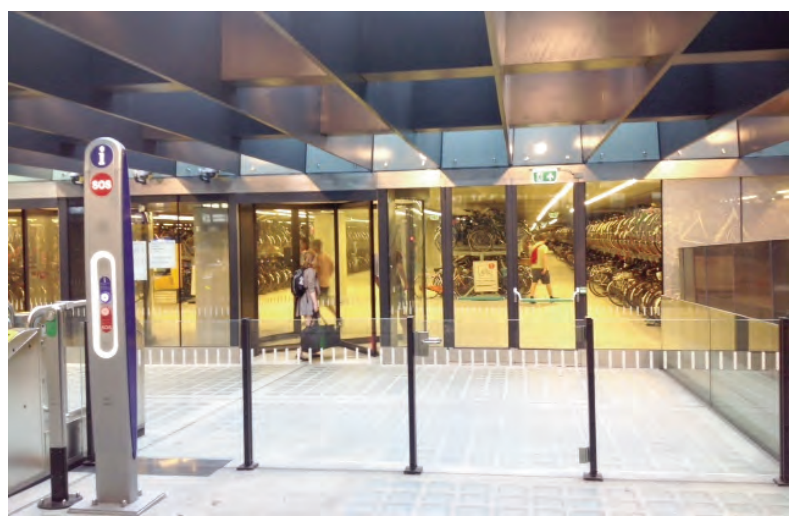

Figure 7. Bicycle Park, Delft Railway Station, Netherlands. (Source: Author, Wednesday 11 May, 2016).

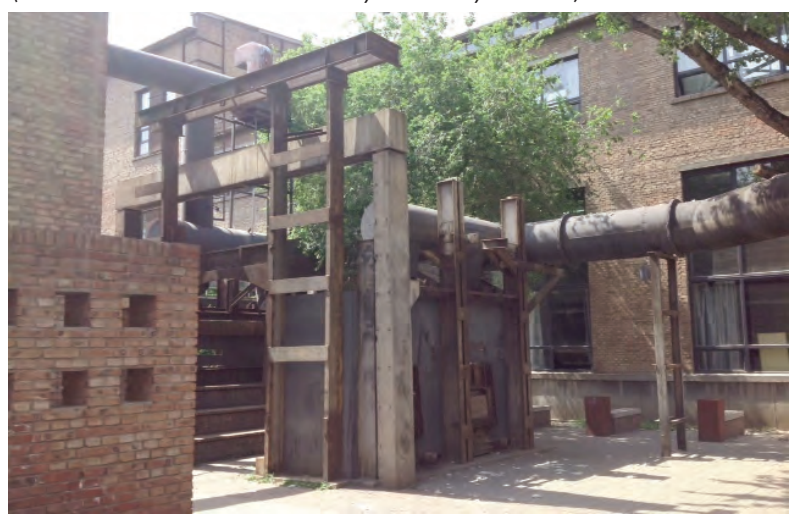

Figure 8. School of Architecture, Inner Mongolia University of Technology, Hohhot, China. (Source: Author, Monday 30 May, 2016).

horizon and our curiosity about the future. Instead of being excited we are worried" (Pallasmaa, 1991).

\section{City of the Mind}

Karl Popper, in his critique of utopia spoke of 'aestheticism' as a deep longing to imagine a society that is not only more rational, but one that has been relieved of all ugliness and constitutes a truly beautiful new world (Popper, 1995). The vision of the Renaissance ideal city with its basis in rational order and geometric purity, offers the classical model of the urban utopia as essentially a 'city of the mind', a

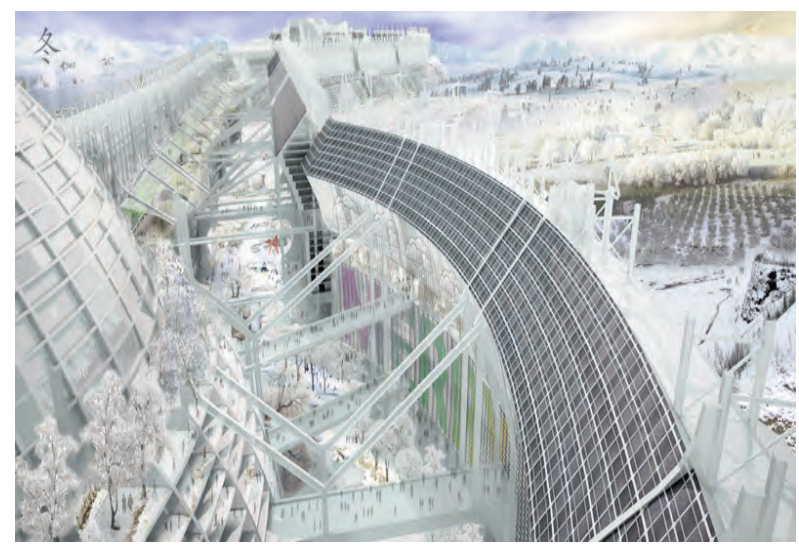

Figure 9. Paolo Soleri's Lean Linear Arterial Arcology model (Source: Cosanti Press/ rendering by Youngsoo Kim, January, 2012).

reference point for the promise of perfection. Although utopianism has been rightly criticised for attempting to subordinate political activity in conformity to a blueprint for the 'Ideal State', the appeal of utopia remains intact, in part, because it allows us to fantasize about the possibility of achieving Mumford's "better world for all". From Plato's Republic and Lao Tzu's Tao Te Ching, utopias have had a long history in art and literature, and as political practice aiming at vast social transformation. In offering alternative visions of the future, many architects and planners have approached the problem from a physical, rather than an ideological, base. During the twentieth century architects such as Tony Garnier (Une Cité Industrielle, 1917); Le Corbusier (La Ville Contemporaine, 1922 and La Ville Radieuse, 1933); Frank Lloyd Wright (Broadacre City, 1934), Constantin Doxiades (Ecumenopolis, 1969) and Paolo Soleri (Arcology, 1969) were inspired by a universal rational morality steeped in the utopian tradition (Rowe and Koetter, 1978).

Soleri's own form of aestheticism is guided by his belief that, 'life is in the thick of things' and it aligns well with Lovelock's Gaia hypothesis. The living process is immensely complex and ever intensifying and creates conditions in which particles of physical matter, in the right setting, can act in ways which are organic and living, and eventually instinctive, selfconscious and spiritual (via what he describes as the "complexity-miniaturization-duration" paradigm). Soleri argued that, in the transformation of the organism from the simple to the complex, matter is becoming spirit (Soleri, 1973). Here he prefigures a utopia of transcendence wherein architecture speaks of the "supremacy of aesthetics over structure and technology" (Moholy-Nagy, 1969). For Soleri it is essentially something 'on the way'. His anticipatory model promises the emancipation of the human spirit via metamorphosis, wherein ecology and architecture are conjoined pieces of both theology and technology, and when designed well the city becomes an instrument for the human evolutionary process. But, despite its theological dimension, it is in the re-casting of the relationship between society and Nature that the Arcology theory conforms to the classical utopian 


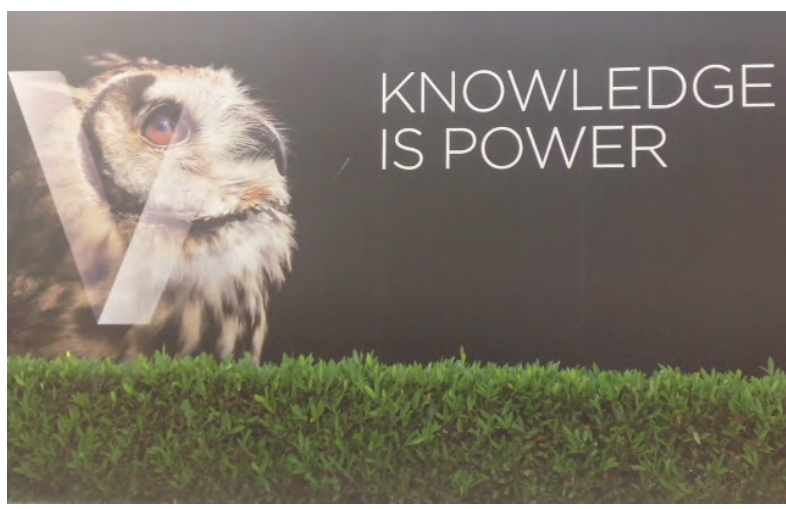

Figure 10. George Best Belfast City Airport, Northern Ireland. (Source: Author, Wednesday 15 June, 2016).

typology. And here, the positive utopian energies of Paolo Soleri's work need to be acknowledged and affirmed. In the face of economic, social and technological uncertainties, he dared to paint a futuristic picture of new kind of society and offer us a glimpse of an alternative future. He stimulated us to think in a participatory way by encouraging our reflection. We were forced to take a stand and critically reconsider our own opinions on how the economy, society and the State should be organised. Utopias, in this sense, act as a 'critical norm', with a potential to develop criteria with which to measure our current social development and environmental setting. They can stimulate theoretical experiments, encourage attempts to break through fixed patterns of thinking, and test unorthodox combinations of ideas. Perhaps Paolo's most important contribution is in encouraging us to rethink human ecology and re-conceptualise the true extent of human impact on the natural environment.

\section{Two Suns - utopia is for everybody}

Paolo was awarded a special prize by the Congress on Utopia in Italy in 1989 [note 3]. His response was to write a paper on why he rejected utopia. He wrote "utopia is for everybody or it is nonsense" (Soleri cited in Zelove and Cousineau, 1997). Nevertheless his early propositions from 1969, when examined through a utopic lens present ideological narratives that confront the myths of the then present social order. Although described as examples of 'miniaturisation' these thirty early projects, were designed for the efficient and rational restructuring of economies and societies on such a massive scale that, to the thousands who flocked in 1970 to the Corcoran Gallery in New York to see them exhibited, they appeared shocking and alien. They nevertheless demanded attention and reflection. In the tradition of megastructural solutions like those of Buckminster Fuller, the Japanese Matabolists, and Archigram, Paolo's early proposals were founded on a spectacular degree of faith in technological progress, seemingly offering a technocentric path towards society's ecological salvation. But by 1975, with the development of the Two Suns Arcology proposal, he had fully endorsed an ecologically-based morality encompassed an integration of five related 'passive' effects:

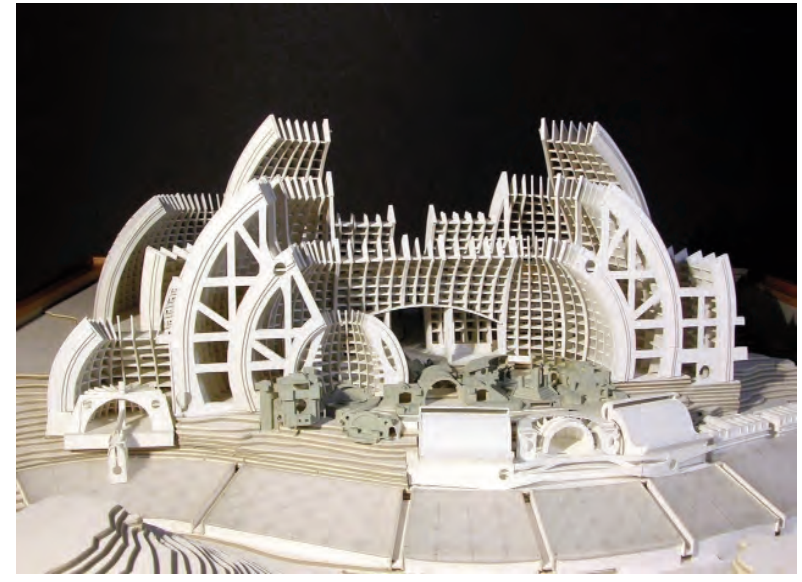

Figure 17. Arcosanti 5000 model (Source: Paolo Soleri/Cosanti Foundation).

The Urban Effect represents the fundamental drive of life. The evolution of the city is the process by which the 'non-living' is infused with life, and the 'living' becomes inventive, conscious, anticipatory, thinking, creational. The Urban Effect is the bridge between matter and spirit and is linked functionally to the four other effects:

- The Urban Effect represents the fundamental drive of life. The evolution of the city is the process by which the 'non-living' is infused with life, and the 'living' becomes inventive, conscious, anticipatory, thinking, creational. The Urban Effect is the bridge between matter and spirit and is linked functionally to the four other effects:

- The Horticulture Effect has ancient origins in the management and cultivation of vegetation.

- The Greenhouse Effect enables the gathering of heat from the sun within a defined and controlled space. When combined with the Horticulture Effect this provides a natural agricultural base.

- The Chimney Effect is the system by which collected warm air is passively channeled as it rises.

- The Apse Effect describes a quarter-sphere structure facing South and thus acting as a sun collector in the cold season and as a sunshade in the warm season. It is a passive "energy machine" running solely on how it displays itself to the varying trajectory of the sun (www.arcosanti.org).

The aim of this integration is a more effective habitat, responsive to the needs of society, and sensitive to the environmental and ecological limits. Two Suns focuses on the development of the central system for the efficient collection, transmission, and consumption of solar energy to support a town or city population. This is to be achieved through the use of terraced greenhouses on the south slope of the city. Solar heat from the greenhouse collectors is redirected to meet basic heating and cooling needs of the entire city, while food for the city's inhabitants is provided by the greenhouses.

The approach encompasses a sense of respect for Nature in its own right as well as for instrumental and functional reasons. It exhibits a concern with ends (an eschatology of decentralised communities) and the proper kind of means (in the 'soft' tech- 
nology of transcendence) and can be viewed as both environmentally benign and democratic. Two Suns aims towards an urban system based on the ecological principles of diversity and homeostasis. Despite many obstacles, rejections and disappointments Paolo tenaciously held to his philosophy until his death in 2013 at the age of 93. In attempting to build a better urban alternative his work straddles conventional values and radical methods associated with various shades of environmentalism. Although his fundamentally human-centred outlook upholds aspects of a fairly traditional (conservative Green) approach to environmental issues his support of the Romantic rebellion against the utilitarian, materialistic values of the 'American Dream', and his advocacy of a more frugal alternative, within self-reliant urban communities modelled on natural ecosystems, prefigures the realisation of a 'neonature' predicated on radical social and environmental reconstruction. If achieved, this would redefine all that, until now, has been considered 'normal' and 'usual'. By envisioning the possibility of re-naturalising the natural environment Paolo's work has contributed to radical ecology's mission of world disclosure.

\section{ARCOSANTI: AN URBAN LABORATORY}

In Virtual Light Gibson describes the 'Bridge' as a place within which a whole range of social experiments can take place (Gibson, 1993). He raises the tricky question of how to imagine alternatives to current urban trends which appear to lay the dead hand of 'zero tolerance' on any form of difference from prescribed social norms. An overemphasis on the social rather than the physical landscape of the city makes vision, in the sense of what can be seen, difficult. A social vision for the city has to have some sense of its physical sites, how they might look and what they might symbolise. While most governments acknowledge that environmental problems are serious and numerous, and that policies must urgently address sustainable development, the concept has a variety of meanings and divergent interpretations, and research has tended to focus on restructuring existing

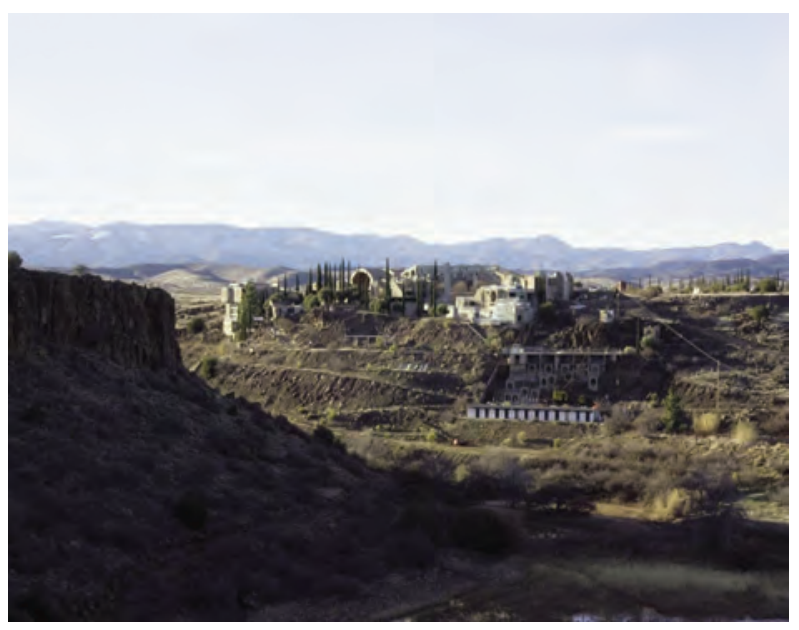

Figure 12. Arcosanti today (Source: Author). cities and conurbations, and on individual parts of the problem (e.g. energy, density, transport, containment, green space, and sense of place), rather than taking a more holistic and systemic approach to new urban development appropriate for an expanding world population.

The problem remains one of the proper evaluation of alternatives and gathering evidence. There is an urgent need for multi-aspect and multidisciplinary research here, since the complex issues will not become tangible unless we can develop laboratories to test micro- and macro-structures of alternative models and test their parameters through critical evaluation (Munro \& Grierson, 2016). Without such centres of investigative research the complex issues of seeking urban sustainability will continue to rely on assumptions.

On top of a low mesa above the Agua Fria river, in the central Arizona desert 70 miles north of Phoenix, Arcosanti, a unique laboratory has been developing slowly since 1970. A project of Soleri's Cosanti Foundation, Arcosanti, has attempted to test and refine the basic physical and cultural tenets of the Arcology, largely aligned with the Two Suns approach, through architectural, environmental, and social research on a micro-level. Described as a "permanent experiment in urban intensity" (Altman and Chemers, 1980) when complete it will house an environmentally benign "learning/doing" community of five to six thousand people, occupying only fifteen acres of land in the midst of an 860-acre nature preserve containing orchards, agricultural fields, canyons and high desert hills. The compact structures of Arcosanti will stretch no more than quarter of a mile on any one side face the Sun to gather its energy. Inside, when complete, the structures will contain the economic, cultural, and social infrastructure normally scattered around a modern city, while providing citizens with up to two thousand square feet of living space per family. A series of orchards will line the North side of the structure, creating a unique fusion of urban and agricultural environments. Outside there will be expansive views of another three thousand acres, leased from Arizona State, to be kept as undeveloped open space.

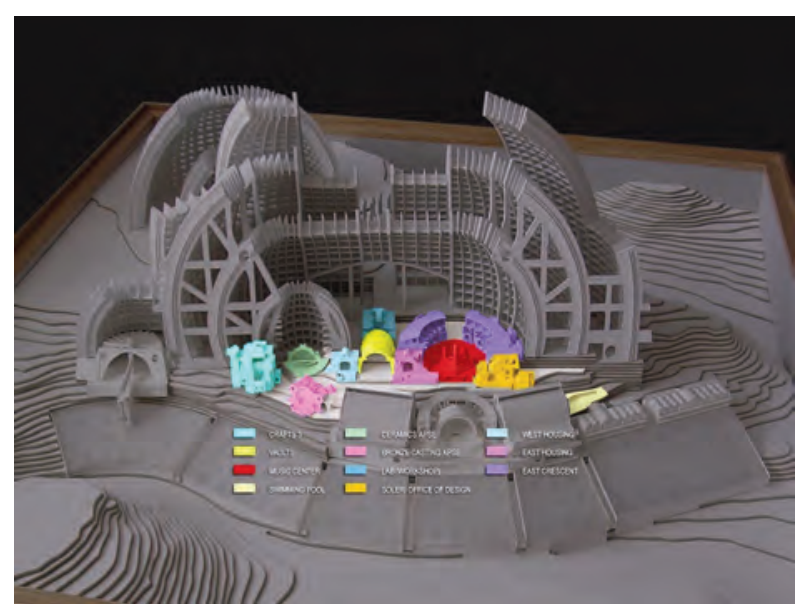

Figure 73. Arcosanti 5000 model: completed buildings (Source: Paolo Soleri/Cosanti Foundation). 
An integral part of the design will be five to seven acres of south-facing sloped greenhouses, an "energy apron" acting as a central system for producing food and collecting energy to support the community.

Arcosanti (meaning 'architecture before things") was the 30th, and last, of the designs to be presented in the book, Arcology: the City in the Image of Man where it was described as a "self-testing school in urban studies" (Soleri, 1969). Paolo advocated the investigation of new urban patterns and structural systems within the construction of a complex that would apply and test these at the modest end of the urban scale (Creagh, 1983). While Arcosanti follows in the tradition of a multitude of experiments in libertarianism, from the Owenite and Fourierist experiments of the early nineteenth century to the counter-cultural communes of the 1960s [note 4], to the profusion of ecovillages, organic farms, and cohousing communities around the world today, the stated priority for the work at Arcosanti, during Soleri's lifetime, lay in the definition of a physical structure, which would be indispensable for the "social organism" that would inhabit it. While the slow pace of construction was a source of frustration (not least to Paolo himself), the 'small experimental' nature of Arcosanti is in keeping with the contemporary Green movement's idealist strategy of change through 'force of example'. From the Centre of Technology (CAT) in Wales to the New Age community at Findhorn, Scotland, much of the practice of much Green politics takes the form of a series of small experiments. Creagh argues that there are problems that can only be faced through investigation on the micro-social level (Creagh, 1983) since intentional communities confront a multitude of questions related to interpersonal relations and everyday life. But this also raises the problem of persuasion that confronts the entire environmental movement. People are required to think in global terms and with respect to events that may, or may not, take place in the future. Porrit (2013) suggests that although Green strategies for change have not yet brought about the fundamental shift that might have been expected, positive visions for change are achievable "if we play our cards right". In terms of the questioning of current social and political practices and the presentation of alternatives, the growing global middle class may well have a central role to play here in being more receptive to new forms of prosperous, healthy, and exciting urban living. But the political economy of democratic capitalist societies, particularly in Western societies, have until now lacked support, and any real encouragement, for implementing models of communal living, since the practical exploration of this means going against the grain. Life at Arcosanti is the antithesis of modern suburban living (lacking mobility, luxury, consumerism) so while it may offer in time what an ecological society needs it hasn't yet been what the consumer wants. The myths of modern life may be full of false promise, but if Arcosanti fails to be persuasive as a feasible living alternative, its ultimate misfortune may be to stand as tangible proof that an ideology of frugality is what most of today's suburbanites fear most.

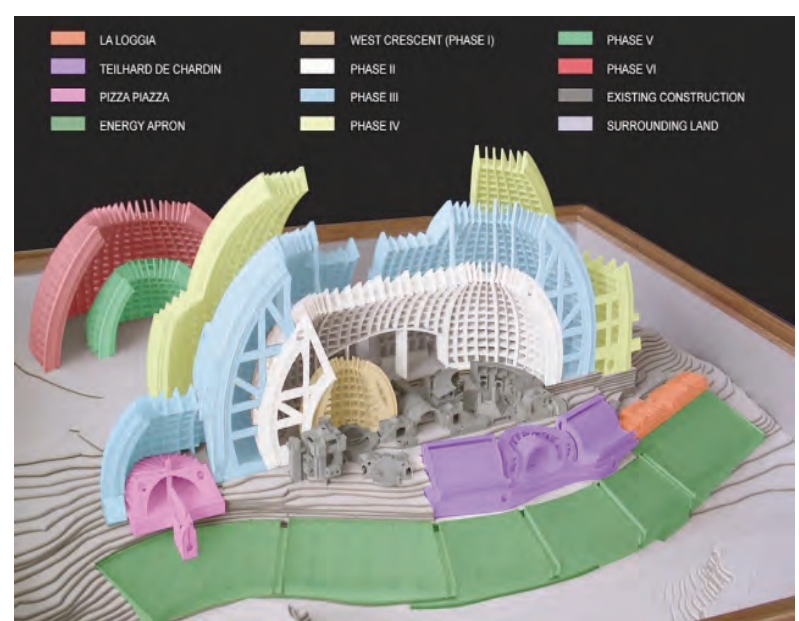

Figure 74. Arcosanti 5000 model: proposed phased development (Source: Paolo Soleri/Cosanti Foundation).

\section{Directing and Steering Progress}

In the decade preceeding his death in 2013, Soleri's expressed view that Arcosanti is largely an informational construct (Soleri, cited in Mayne, 1993) was perhaps born of necessity rather than desire. While Arcosanti today retains an influential presence in academia and on the internet (www.arcosanti.org) it continues to be built by unskilled volunteers, and today the limited progess in construction is being largely funded through the sale of the wind bells made there, and at Cosanti in Scottsdale. Currently, a lack of resources hinders attempts to achieve progress. While the slow pace may demonstrate the "small is beautiful" and "voluntary simplicity" ethos that allowed Paolo to keep a close control of design developments, such independence has come with a price. In the postSoleri era Arcosanti continues in its struggle to become economically self-sustaining. French sociologist, philosopher, and cultural theorist Jean Baudrillard (1988) wrote of Arcosanti that it "gathers together all the 'soft' technologies in the heart of the desert" (Baudrillard, 1988). It certainly aspires to this and by attempting to do so over a period of almost fifty years, the project already offers tried and tested potential solutions to the wider challenges of urban sustainability. The urban laboratory has involved the creation of an environment where the social, cultural, agricultural and industrial processes, and the associated production of energy, are being intensified while, at the same time, limiting the impact of the settlement on the natural environment, and minimising its consumption of natural resources. It represents an attempt to address questions of the sustainability of cities, while demonstrating a deep and long-held commitment to ecological ideas. However the future development of Arcosanti, as a viable alternative, now requires private and/or public agency to raise the capital, labour and materials that would allow it to demonstrate, on a larger scale, the ecological principles inherent in the concept. Under previous conditions, neither Paolo nor Arizona State were willing to allow this to happen. Those conditions have now changed not least through a renewed 
committment to achieve progress on its core mission.

There are some recent positive signs that the non-profit educational organisation, the Cosanti Foundation's goal to actively pursue lean alternatives to urban sprawl, based on the Arcology theory, can still be achieved. The Foundation's Board of Directors has recently established (in 2014) a Strategic Plan Steering Committee, comprising of residents and alumni participants that is now working with the Foundation, to attract renewed levels of financial and human resource to support construction and secure Arcosanti's future. Among the Steering Committe's goals, as part of program development, is to establish partnerships for global initiatives, and to engage in critical inquiry with educational partners. One such initiative is the recent collaboration with the Department of Architecture at the University of Strathclyde Glasgow in Scotland which has seen the launch of a new postgraduate course, the MSc Sustainable Engineering: Architecture and Ecology [note 5]. The new course, delivered within the University's renowned Faculty of Engineering, provides students with a unique opportunity to study for a Masters degree while living and working at Arcosanti. Students on the course spend one semester studying at the city centre campus in Glasgow, completing classes in a range of topics from sustainability and urban theory to energy resources and project management. They then travel to Arizona to complete a second semester consisting of a theoretical class on Arcology and a practical interdisciplinary group project working closely on the current research needs, allowing them to apply knowledge and theory to real life problems at the urban laboratory. Thus with a first hand experience of both the idealism of Arcology and the pragmatism of Arcosanti, they might be better placed to unite desire with analysis [note 6].

While Arcosanti's orientation should continue to be towards transcendence and the achievement of an end in "a fully conscious Universe" it is not countercultural, sectarian or religious. Neither is it a meditation centre or a neo-monastic retreat. Rather, as an urban laboratory, Arcosanti should keep its ear to the ground physically, theologically and aesthetically as it attempts to define and critically evaluate a working prototype, that can be influential in changing the social and environmental conditions of the present while aiming at an ideal and unknowable society that might inhabit it in the distant future. Arcosanti, in Umberto Eco's terms might be seen to exhibit the symbolic importance of architecture by accommodating both its "variable primary functions" (its conventional use as living/working/learning community) and its "open secondary functions" (symbolically as a prototype of Arcology) (Eco, 1990). In Soleri's own words Arcosanti is "a quest for what it does not have" (Soleri, 1986). In this way the laboratory becomes both the 'media' and the 'message'. While it fulfils the secondary function of architecture in acting as a symbol Arcosanti is also a real place where people will have a future because they are building one (Grierson, 1997). This is the flesh on the utopia of transcendence. Those who live, work and learn at the labora-

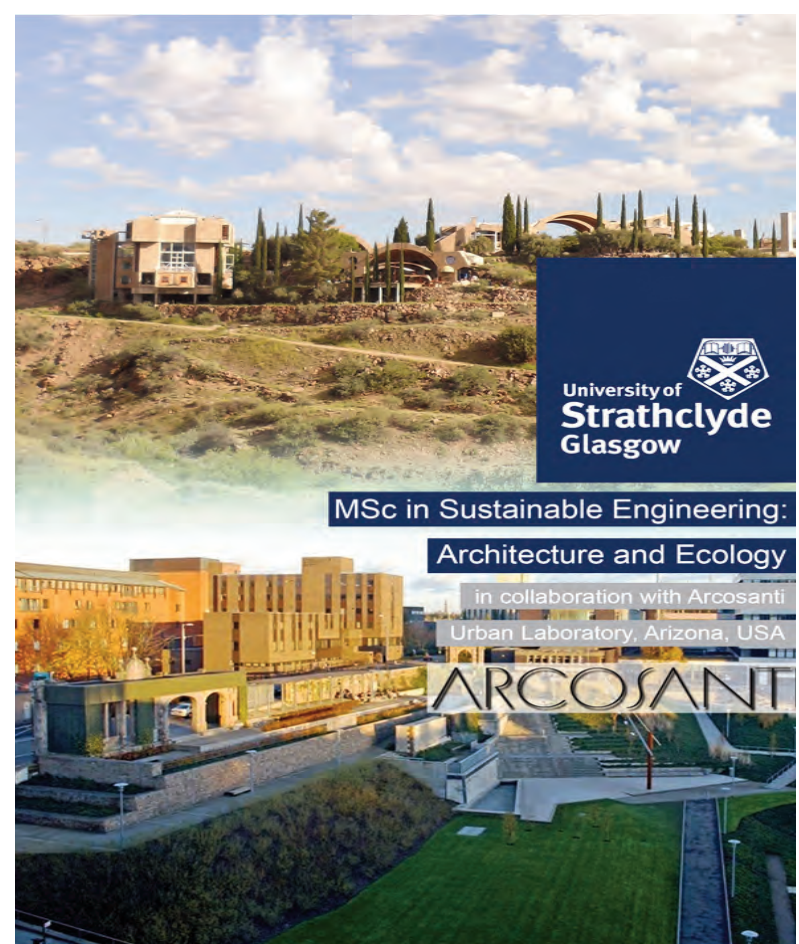

Figure 15. MSc Sustainable Engineering: Architecture and Ecology course leaflet (Source: Author).

tory know that they are in the middle of something that is essentially 'on the way'. Almost fifty years after the first stone was cut at Arcosanti volunteers are still there, and on good days still pouring concrete. Yes, time is precious but then the challenge is immense. There's still no desperate rush. There's no real evidence of a bandwagon of environmental despair, just a daily work schedule, an educational program, and a quiet pervasive hope. The business of the urban laboratory will never really be finished but the last few years seem to have brought renewed focus, and a determination to demonstrate why it is that the work there can support a better alternative, and in time a better world for all.

\section{Notes}

[1] Schopfer Associates have produced a concept design for the $\mathrm{NOAH}$ (New Orleans Arcology Habitat) in 2009 and a floating arcology for Boston harbour (BoA) in 2010.

[2] American philosopher Arthur C. Danto, in 1990, announced "the end of art'. Hans Belting has spoken of "the end of art history". In 1990, Alvin Kernan, the American professor of the humanities published The Death of Literature. In 1967 the French composer and conductor Boulez said, "Blow up the opera houses." More recently, in 1989, the American political historian Francis Fukuyama brought the notion into a wider context in a controversial essay, The End of History.

[3] The Utopus Award was presented by the Third International Conference of Utopian Studies at the Universita Degli Studi di Genova in Reggio Calabria, Italy.

[4] Such as Drop City, Colorado and The Farm in Tennessee.

[5] www.strath.ac.uk/courses/postgraduatetaught/sustainableengineeringarchitectureecology/ 
[6] I am indebted to Jeff Stein, Tomiaki Tamura, Roger Tomalty, Mary Hoadley, and Scott Riley for their support and encouragement in establishing and significantly contributing to the new MSc, and to fellow members of the Steering Committee for (hopefully) understanding that valid contributions to the work can take many forms.

\section{REFERENCES}

ALTMAN, I. and CHEMERS, M. M. 1980. Culture and Environment. Cambridge: Cambridge University Press

BAUDRILLARD, J. 1988. New York in ed. Turner, C. 'America'. London: Verso

BLAKE, P. 1969. Foreword in Soleri, P. Arcology: City in the Image of Man. Arizona: Cosanti Press

CAPRA, F. 1982. The Turning Point. New York: Simon and Schuster

CREAGH, R. 1983. Laboratoires de I'Utopie: Les Communautés Libertaires aux Etats-Unis. Paris: Payot

DOBSON, A. 2007. Green Political Thought. New York: Eco Books

ECO, U. 1990. Travels in Hyper Reality. New York: Harcourt

GIBSON, W. 1993. Virtual Light. London: Penguin

GRIERSON, D. 1997. Unfinished Business at the Urban Laboratory in eds. Barker. C. and Tyldesley, M. 'A Selection of Papers from the Fifth International Conference on Alternative futures and Popular Protest', Volume 1. Manchester: Manchester Metropolitan University

GRIERSON, D. 2003. Arcology and Arcosanti: toward a sustainable built environment. Electronic Green Journal, Volume 18

GRIERSON, D. 2014. Technology and Ecology in ed. Humphreys, D, and Spencer S. 'Transitions to Sustainability: Theoretical Debates for a Changing Planet'. Illinois: Common Ground Publishing

LOVELOCK, J. 2009. The Vanishing Face of Gaia. New York: Basic Books

MAYNE, D.S. 1993. Soleri's Cities: Architecture for the Planet Earth and Beyond. New York: Public Media Incorporated

MOCK, E. B. 1949. The Architecture of Bridges. New York: Museum of Modern Art

MOHOLY-NAGY, S. 1969. Cited in Soleri, P. 1969. Arcology: City in the Image of Man. Arizona: Cosanti Press

MUMFORD, L. 1934. Technics and Civilization. New York: Harcourt, Brace \& Company

MUNRO, K. and GRIERSON, D. 2016. Towards the Development of a Space/Nature Syntax at Arcosanti in eds. Grierson, D. and Salama, A. 'Advances in Sustainable Architecture and Urbanism', Open House International (OHI), Volume 41, Issue 4

OSTLER. T. 1994. Preaching in the Wilderness in 'Building Design $(B D)^{\prime}$. February 18, 1994

PALLASMAA, J. 1991. Architecture in Miniature. Helsinki: Museum of Finnish Architecture

PFEIFFER, B. B. 1982. Frank Lloyd Wright: Letters to Apprentices. Fresno: California State University

POPPER, K. 1995. In Search of a Better World. Cambridge: London: Routledge

PORRIT, J. 2013. The World We Made. London: Phaidon

ROWE, K. and KOETTER, F. 1978. Collage City. Boston: MIT Press

SKOLIMOWSKI. H. 1971. Paolo Soleri: the Philosophy of Urban
Life in 'Architecture Association quarterly (AAQ)' Volume 3, Issue 1. London: Architectural Association

SOLERI, P. 1969. Arcology: City in the Image of Man. Arizona: Cosanti Press

SOLERI, P. 1973. The Bridge Between matter and Spirit is Matter Becoming Spirit. New York: Anchor Press/Doubleday

SOLERI, P. 1986. Technology and Cosmogenesis. Minnesota: Paragon House

STANISHEV. G. 1993. Soleri's Laboratory in 'World Architecture $21^{\prime}$. Rio de Janeiro: International Forum of Young Architects.

THOMPSON, W, I. 1973. Passages About Earth. New York: Harper and Row

ZELOV, C, and COUSINEAU, P. 1997. Design Outlaws on the Ecological Frontier. Philadelphia: Knossus Publishing

\section{Author(s):}

\section{David Grierson}

Department of Architecture

University of Strathclyde

Email: d.grierson@strath.ac.uk 